Vol.2 No.2 Hal. $08-16$

September 2019

\title{
Pengaruh Bi Rate Terhadap Indeks Harga Saham Jakarta Islamic Index (JII) Yang Terdaftar di Bursa Efek Indonesia
}

\author{
Ardhansyah Putra Harahap
}

Universitas Muslim Nusantara Al-Wasliyah Medan

Ardhansyahputra86@yahoo.com

\begin{abstract}
ABSTRAK
Penelitian ini bertujuan untuk mengetahui pengaruh BI Rate terhadap indeks harga saham Jakarta Islamic Index (JII) selama periode 2014-2016. Teknik pengambilan sampel yang dilakukan dalam penelitian ini merupakan metode purposive sampling dan berdasarkan kritera yang telah ditentukan diperoleh 31 sampel dari 36 populasi yang memenuhi kriteria. Teknik analisis data yang digunakan dalam menguji normalitas data menggunakan One-Sample Kolmogorov-Smirnov, sedangkan dalam menuji hipotesis penelitian ini yaitu dengan analisis regresi sederhana dan uji F yang dilakukan dengan bantuan software SPSS ver. 20. Dari analisis regresi sederhana BI Rate bernilai -3402,691. Hasil dari pengujian hipotesis secara parsial BI Rate sebesar 3,746 dengan nilai signifikansi masing-masing sebesar 0,000 dan 0,001. Dan nilai Adjusted $\mathrm{R}^{2}$ memiliki nilai sebesar 0,932 atau $93,2 \%$. Dari hasil analisis dan uji hipotesis menunjukkan bahwa BI Rate berpengaruh dan signifikan terhadap indeks harga saham Jakarta Islamic Index di Bursa Efek Indonesia.
\end{abstract}

Kata Kunci : BI Rate, Indeks Harga Saham, Bursa Efek

\begin{abstract}
This study aims to determine the effect of the BI rate on the Jakarta Islamic Index (JII) stock price index during the 2014-2016 period. The sampling technique used in this study is a purposive sampling method and based on predetermined criteria obtained 31 samples from 36 populations that meet the criteria. The data analysis technique used in testing the normality of data uses Kolmogorov-Smirnov One-Sample, while in testing the hypothesis of this study is a simple regression analysis and F test performed with the help of SPSS software ver. 20. From a simple regression analysis, the BI Rate is $-3402,691$. The results of partial testing of the BI Rate were 3,746 with a significance value of 0,000 and 0,001, respectively. And the value of Adjusted R2 has a value of 0.932 or $93.2 \%$. From the results of the analysis and hypothesis testing, it shows that the BI rate has a significant and significant effect on the Jakarta Islamic Index stock price index on the Indonesia Stock Exchange.
\end{abstract}

Keywords : BI Rate, Stock Price Index, Stock Exchange 
Julianto H, AL Kausar S : Pengaruh Etika Kerja Islami Terhadap Kinerja Dosen (Studi Kasus Pada Universitas Muslim Nusantara AL- Wasliyah Medan)

\section{PENDAHULUAN}

\section{Latar Belakang}

Keberadaan pasar modal dalam aktifitas perekonomian sebuah negara menjadi alternatif sumber dana bagi perusahaan dan juga bagi para investor untuk berinvestasi dengan cara memperjualbelikan saham-saham perusahaan yang sudah go public. Selain memiliki sumber pendanaan lain selain bank yang memiliki kewajiban membayar bunga secara periodik dan teratur, menjadi perusahaan yang sudah go public memberikan keuntungan lain berupa cost capital yang rendah. Sedangkan bagi para investor sebagai surplus unit menyalurkan dana yang dimilikinya ke deficit unit seperti perusahaan merupakan kegiatan investasi yang bertujuan untuk meningkatkan kekayaan dirinya dengan memilih berbagai investasi yang sesuai dengan tingkat keuntungan dan tingkat resiko yang diharapkan sehingga memungkinkan terjadinya alokasi dana yang efisien. Baik untuk investor maupun bagi perusahaan, keduanya memerlukan suatu wadah untuk mempertemukan kepentingan kedua pihak dan pasar modal merupakan tempat yang sesuai dengan kebutuhan mereka. Perbedaan umum antara pasar modal konvensional dan pasar modal syariah pada umumnya terlihat pada instrumen dan mekanisme transaksinya, sedangkan perbedaan nilai indeks konvensional dan indeks syariah terletak pada kriteria saham emiten yang harus memenuhi prinsip-prinsip syariah. Ketentuan yang termaktub mengandung unsur pembagian hasil berdasarkan nisbah ekuivalen atau yang dikenal dengan istilah mudharabah.

\section{Perumusan Masalah}

Pada tahun 2015 terjadi penurunan indeks saham syariah Jakarta Islamic Index (JII). Pada awal tahun 2015 indeks JII masih berkisar di angka 668,46. Namun, sepanjang tahun 2015 angka indeks terus menunjukan penurunan hingga mencapai penurunan terendah hingga menyentuh angka 553,86 pada 27 September 2015. Pada umumnya indeks JII berkisar pada level 660 sampai 700, Pada saat data dikutip, angka indeks menunjukkan angka 704,22 pada 30 Maret 2018. Selisih angka indeks dari pembukaan tahun hingga mencapai titik terendah pada 27 September 2015 mencapai penurunan sebesar -150,36 atau -22,50\%. Meski pada bulan September mengalami penurunan yang cukup rendah, namun pada akhir tahun indeks JII sedikit mengalami sedikit penguatan walau belum mencapai angka indeks seperti awal tahun yang ditutup dengan angka 603,34 atau 8,20\%.

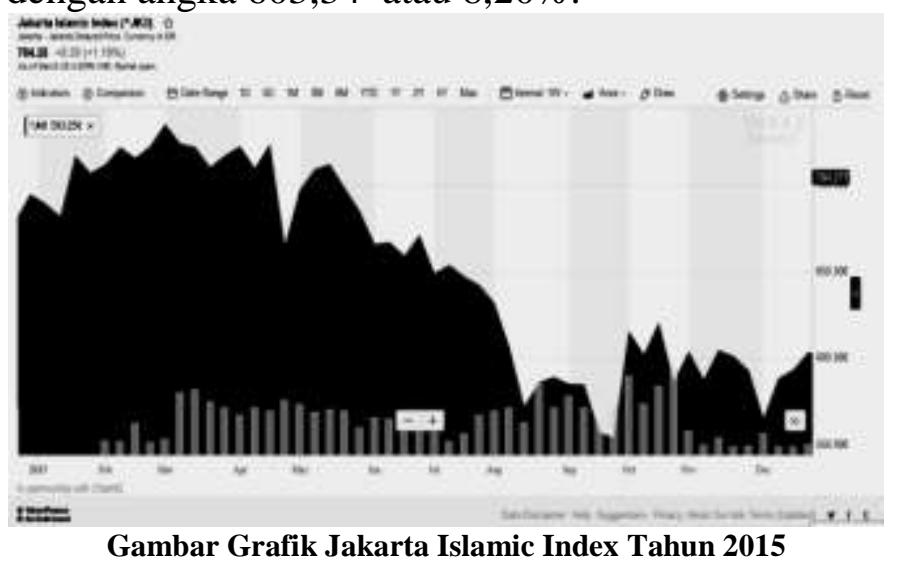

Dengan penurunan angka indeks banyak investor yang melepas saham dan keluar sejenak dari bursa efek untuk mengantisipasi kehilangan dana sehingga hal itu berdampak pada mengendurnya bisnis unit yang tergabung. Hal tersebut menyebabkan ekspektasi pasar terhadap pertumbuhan ekonomi di Indonesia juga turun.

\section{Tujuan Penelitian}

Penelitian ini dilakukan untuk mengetahui seberapa besar pengaruh BI Rate terhadap indeks harga saham Jakarta Islamic Index (JII). Dengan mengetahui hal tersebut, para investor akan 
dapat mempertimbangakan berbagai aspek dalam menilai perkembangan atau penurunan indeks harga saham sehingga kegiatan investasi para investor di bursa efek memiliki pertimbangan yang lebih matang.

\section{Manfaat Penelitian}

Bertujuan untuk mendapat teknik Pengelolaan ini berdasarkan sifat jujur, amanah dan dapat dipercaya, sehingga dapat memberikan manfaat baik secara ekonomi duniawi berupa tingkat pengembalian investasi maupun secara ukhrawi atau amal ibadah. Sebagai salah satu implementasi upaya strategis pengembangan produksi berbasis syariah di Pasar Modal. OJK telah menerbitkan Daftar Efek Syariah (DES) melalui Surat Keputusan Dewan Komisioner OJK. Penerbitan keputusan tersebut didasarkan pada review berkala yang dilakukan OJK atas laporan keuangan dan informasi tertulis lain yang diperoleh dari emiten perusahaan publik. Efek syariah yang termuat dalam DES periode I meliputi 321 saham efek jenis Saham Emiten dan Peerusahaan Publik serta Efek Syariah lainnya dan DES Periode II meliputi 345 Efek jenis Saham Emiten dan Perusahaan Publik serta Efek syariah lainnya. Sejak diterbitkannya DES perode II pada tanggal 24 November 2016 sampai akhir tahun 2016, terdapat penambahan 2 saham yang masuk dalam DES yang diperoleh dari hasil penelahaan DES insidentil bersamaan dengan efektifnya pernyataan pendaftaran Emiten yang melakukan penawaran umum perdana saham yaitu saham PT Prodia Widyahusada Tbk. dan saham PT Bintang Oto Global Tbk. Secara kesuluruhan, saham yang termasuk dalam DES hingga akhir tahun 2016 berjumlah 347 saham.

\section{Kajian Literatur BI Rate}

Menurut Anton (2014:124) BI rate adalah suku bunga kebijakan yang mencerminkan sikap kebijakan moneter yang ditetapkan oleh Bank Indonesia dan diumumkan kepada publik. BI rate diumumkan oleh Dewan Gubernur Bank Indonesia setiap bulannya. Bank Indonesia pada umumnya akan menaikkan BI rate apabila inflasi kedepan diperkirakan melampaui sasaran yang ditetapkan, sebaliknya pula Bank Indonesia akan menurunkan BI rate apabila inflasi kedepan diperkirakan berada dibawah sasaran yang ditetapkan. Penetapan respon kebijakan moneter Bank Indonesia dilakukan dalam Rapat Dewan Gubernur (RDG). Rapat tersebut diadakan pada minggu pertama setiap bulannya, guna melakukan asesment (penilaian) menyeluruh terhadap perkembangan kondisi makroekonomi dan kebijakan terkini, serta proyeksi ekonomi kedepannya, termasuk inflasi. Sikap kebijakan moneter tersebut juga diimplementasikan pada operasi moneter yang dilakukan Bank Indonesia melalui pengelolaan likuiditas di pasar uang untuk mencapai sasaran opeasional kebijakan moneter. Tujuan akhir kebijakan moneter adalah menjaga dan memelihara kestabilan nilai rupiah yang salah satunya tercermin dari tingkat inflasi yang rendah dan stabil. Untuk mencapai tujuan itu, Bank Indonesia menetapkan suku bunga kebijakan BI rate sebagai instrumen kebijakan utama untuk memengaruhi aktivitas kegiatan perekonomian dengan tujuan akhir pencapaian inflasi. Namun jalur atau transmisi dari keputusan BI rate sampai dengan pencapaian sasaran inflasi tersebut sangat kompleks dan memerlukan waktu.

\section{Hubungan BI Rate dengan Harga Saham}

Ketika Bank Indonesia menaikkan bunga acuan, biasanya diikuti oleh bank - bank umum dengan menaikkan bungan acuan pinjaman. Hal ini menjadikan beban biaya tambahan bagi perusahaan yang menggunakan pinjaman dari bank biaya operasi. Beban biaya tersebut akan mengurangi tingkat keuntungan perusahaan, sehingga jumlah deviden yang diterima investor semakin sedikit dan saham cenderung dijual. Ketika banyak saham yang dijual maka harga saham semakin menurun. Dengan demikian, apabila BI menaikkan bunga acuan, maka harga saham cenderung turun. 
Julianto H, AL Kausar S : Pengaruh Etika Kerja Islami Terhadap Kinerja Dosen (Studi Kasus Pada Universitas Muslim Nusantara AL- Wasliyah Medan)

\section{Pasar Modal}

Bursa efek menurut Pasal 1 Ayat (4) UU No. 8 tahun 1995 tentang Pasar Modal adalah pihak yang menyelenggarakan dan menyediakan sistem dan/atau sarana untuk mempertemukan penawaran jual dan beli efek pihak-pihak lain dengan tujuan memperdagangkan efek di antara mereka. Menurut Soemitra (2015:111) pasar modal secara umum merupakan suatu tempat bertemunya para penjual dan pembeli untuk melakukan transaksi dalam rangka memperoleh modal. Penjual dalam pasar modal merupakan perusahaan yang membutuhkan modal (emiten), sehingga mereka berusaha untuk menjual efek-efek di pasar modal. Sedangkan pembeli (investor) adalah pihak yang ingin membeli modal di perusahaan yang menurut mereka menguntungkan. Sedangkan pasar modal syariah (Soemitra:2015) secara sederhana dapat diartikan sebagai pasar modal yang menerapkan prinsip-prinsip syariah dalam kegiatan transaksi ekonomi dan terlepas dari hal-hal yang dilarang seperti: riba, perjudian, spekulasi dan lain-lain. Pasar modal syariah secara prinsip berbeda dengan pasar modal konvensional. Sejumlah instrumen syariah sudah digulirkan dipasar modal Indonesia seperti dalam bentuk saham dan obligasi dengan kriteria tertentu yang sesuai dengan prinsip syariah. Pasar modal syariah merupakan pasar modal yang seluruh mekanisme kegiatannya terutama mengenai emiten, jenis efek yang diperdagangkan dan mekanisme perdagangannya telah sesuai dengan prinsip-prinsipsyariah. Sedangkan yang dimaksud dalam peraturan perundang-undangan di bidang Pasar Modal yang akad, pengelolaan perusahaan, maupun cara pengelolaannya memenuhi prinsip-prinsip syariah. Adapun yang dimaksud dengan prnsip-prinsip syariah adalah prinsip yang didasarkan oleh syariah ajaran Islam yang penetapannya dilakuakn oleh DSN-MUI melalui fatwa.

\section{Instrumen Pasar Modal Syariah Indonesia}

Pasar modal syariah secara khusus memperjualbelikan efek syariah. Efek syariah adalah efek yang akad, pengelolaan perusahaan, maupun cara penerbitannya memenuhi prinsip-prinsip syariah yang didasarkan ajaran Islam yang penetapannya dilakukan oleh DSN-MUI dalam bentuk fatwa. Secara umum ketentuan penerbitan efek syariah haruslah sesuai dengan prinsip syariah di pasar modal. Prinsip-prinsip syariah di pasar modal adalah prinsip-prinsip hukum Islam dalam kegiatan di bidang pasar modal berdasarkan fatwa Dewan Syariah Nasional Majelis Ulama Indonesia (DSN-MUI), baik fatwa DSN-MUI yang ditetapkan dalam peraturan Bapepam dan LK.

\section{METODE PENELITIAN \\ Desain Penelitian}

Berdasarkan data yang digunakan, penelitian ini termasuk penelitian deskriptif kuantitatif karena mengacu pada mendeskripsikan penghitungan dan analisis data berupa angka-angka. Data yang berupa angka tersebut kemudian diolah dan dianalisis untuk mendapatkan suatu informasi ilmiah dibalik angka-angka tersebut.

\section{Populasi dan Sampel}

Populasi merupakan keseluruhan objek atau subjek yang berada yang pada suatu wilayah dan memenuhi syarat-syarat tertentu berkaitan dengan masalah penelitian atau keseluruhan unit atau individu dalam ruang lingkup yang akan diteliti (Nanang Martono:2012). Populasi dalam penelitian ini yaitu seluruh seluruh data bulanan Jakarta Islamic Index pada periode 2014-2016 yaitu sebanyak 36 bulan. Pemilihan sampel dalam penelitian ini dengan Jakarta Islamic Index sebagai variabel terikatnya dilakukan melalui metode purpose sampling, yaitu pemilihan sampel berdasarkan kriteria dan sistematika tertentu yang bertujuan untuk 
Julianto H, AL Kausar S : Pengaruh Etika Kerja Islami Terhadap Kinerja Dosen (Studi Kasus Pada Universitas Muslim Nusantara AL- Wasliyah Medan)

mendapatkan sampel yang representatif. Untuk sampel Jakarta Islamic Index, kriteria yang digunakan adalah sebagai berikut:

1. Nilai Jakarta Islamic Index (JII) update 2014-2016

2. Nilai BI Rate update $2014-2016$

\section{Lokasi dan Waktu Penelitian}

Lokasi Penelitian

Penelitian ini dilakukan di Bursa Efek Indonesia dengan alamat website www.idx.co.id dan Bank Indonesia dengan alamat website www.bi.go.id.

\section{Waktu Penelitian}

Adapun waktu penelitian dilakukan selama 3 bulan dari bulan Desember 2018 s/d Maret 2019.

\section{Variabel dan Indikator}

Variabel didefenisikan sebagai konsep yang memiliki variasi atau memiliki lebih dari satu nilai. Penelitian berjumlah satu variabel dependen (variabel bebas) dan dua variabel independen (variabel terikat). Variabel dependen yang merupakan variabel yang memengaruhi variabel lain atau mengahasilkan akibat pada variabel yang lain yang pada umumnya berada dalam urutan tata waktu yang terjadi lebih dahulu. Sedangakan variabel independen merupakan variabel yang diakibatkan atau dipengaruhi oleh variabel bebas. Adapun variabel dependen dan variabel independen dalam penelitian ini yaitu:

1. Variabel Indeks Harga Saham Jakarta Islamic Index (JII) (Y)

Jakarta Islamic Index merupakan salah satu indeks saham yang menghitung indeks harga rata-rata saham untuk jenis saham yang memenuhi kriteria syariah. Indokator yang digunakan dalam menentukan indeks harga saham Jakarta Islamic Index (JII) berupa Moving Avarege, Moving Avarage Envelope, Moving Avarage Deviation, Bollinger Bands, RSI, MACD dan beberapa indikator lain. Menurut Hidayat (2011) alat ukur yang digunakan dalam mengukur indeks harga saham ini berupa angka indeks yang dikeluarkan oleh bursa efek indonesia dan diakses melalui website https://finance.yahoo.com.

2. Variabel BI Rate $\left(\mathrm{X}_{2}\right)$

BI Rate adalah suku bunga kebijakan yang mencerminkan sikap kebijakan moneter yang ditetapkan oleh Bank Indonesian dan diumumkan kepada publik. Indikator yang digunakan dalam menetukan BI rate berupa tingkat inflasi, neraca perdagangan, tingkat produksi dan angka pengangguran. Berdasarkan penjelasan BI Rate dalam website Bank Indonesia, alat ukur yang digunakan berupa persentase tingkat suku bunga berdasarkan hasil dari rapat Dewan Gubernur Bank Indonesia yang diumumkan melalui siaran pers.

\section{Tehnik Pengumpulan Data}

Data yang diteliti merupakan data sekunder. Adapun teknik yang digunakan dalam pengumpulan data penelitian ini antara lain, yaitu:

1. Teknik kepustakaan, yaitu penelitian yang mendapatkan landasan yang kuat tentang teori, baik yang berupa rumus-rumus teknis pengumpulan maupun teori-teori yang mendukung objek penelitian. Sumber riset kepustakaan yang dilakukan yaitu melalui buku-buku text book, literarut-literatur, jurnal-jurnal, maupun internet serta sumber lain yang relevan dengan objek permasalahan yang diteliti.

2. Teknik dokumentasi, yaitu penelitian yang mempelajari dokumen-dokumen yang menjadi sumber data yang digunakan untuk melengkapi penelitian dan dalam penelitian ini, data yang diperlukan yaitu data sekunder berupa laporan keuangan tahunan yang diterbitkan oleh perusahaan, laporan bursa efek indonesia, jurna-jurnal dan literatur-literatur lainnya yang berhubungan dengan objek yang sedang diteliti. 
Julianto H, AL Kausar S : Pengaruh Etika Kerja Islami Terhadap Kinerja Dosen (Studi Kasus Pada Universitas Muslim Nusantara AL- Wasliyah Medan)

\section{Teknik Analisis Data}

Untuk mengetahui pengaruh BI Rate terhadap indeks harga saham Jakarta Islamic Index (JII) dilakukan analisis regresi linear sederhana dan pengujian hipotesis menggunakan Uji $t$ (Parsial) dan $\mathrm{R}^{2}$ (Koefisien Determinasi). Pengolahan data dilakukan dengan bantuan proegram aplikasi komputer SPSS 20 for windows.

\section{Analisis Regresi}

\section{Analisis Regresi Linear Sederhana}

Analisis regresi linear sederhana ini digunakan untuk menguji hubungan/ korelasi/ pengaruh satu variabel bebas terhadap satu variabel terikat, yaitu:

$\mathrm{H}_{1}$ : Pengaruh BI Rate terhadap indeks harga saham Jakarta Islamic Index (JII) di Bursa Efek Indonesia, yang dirumuskan sebagai berikut:

$Y=a+b x+e$

Keterangan:

Y : Indeks Harga Saham Jakarta Islamic Index (JII)

a : Konstanta

b : Koefisisan regresi

X : Variabel bebas

e : Standar error

\section{Pengujian Hipotesis}

Analisis ini digunakan untuk mengetahui variabel independen mempunyai pengaruh terhadap variabel dependen. Model regresi untuk menguji hipotesis dalam penelitian ini menggunakan uji signifikansi parameter individual (Uji Statistik t).

\section{Uji Parsial (Uji-t)}

Uji parsial ini bertujuan untuk menunjukkan seberapa besar pengaruh satu variabel individu secara parsial dalam menerangkan variabel dependen. Bentuk pengujiannya adalah melalui $\mathrm{H}_{0}$ dan $\mathrm{H}_{\mathrm{a}}$. (Sugiono, 2012:84). Rumusan hipotesis untuk menguji pengaruh variabel bebas terhadap variabel independen secara parsial adalah sebagai berikut:

$\mathrm{H}_{0}$ : Variabel bebas tidak berpengaruh signifikan terhadap variabel tidak bebas

$\mathrm{H}_{\mathrm{a}}$ : Variabel bebas berpengaruh signifikan terhadap variabel tidak bebas

Pada penelitian ini terdapat nilai $\mathrm{P}$ value yang dibandingkan dengan $\alpha=0,05$. Kriteria penerimaan menggunakan nilai $\mathrm{H}_{0}$ apabila hasil $\mathrm{H}_{0}$ menunjukkan nilai $>5 \%$ atau 0,05 , maka dapat disimpulkan $\mathrm{H}_{0}$ diterima. Sedangkan apabila hasil $\mathrm{H}_{0}$ menunjukkan nilai $<5 \%$ atau 0,05, maka dapat disimpulkan $\mathrm{H}_{0}$ ditolak.

\section{Koefisien Determinasi $\left(\mathbf{R}^{2}\right)$}

Koefisien determinasi $\left(\mathrm{R}^{2}\right)$ pada intinya mengukur seberapa jauh kemampuan model dalam menerangkan variasi variabel dependen. Besarnya koefisien determinasi ini adalah 0 sampai dengan 1 . Nilai adjusted $R^{2}$ yang kecil berarti kemampuan variabel-variabel independen dalam menjelaskan variabel-variabel dependen amat terbatas. Nilai yang mendekati satu berarti varaibel- varaibel independen memberikan hampir semua informasi yang dibutuhkan untuk memprediksi varaibel-varaibel dependen.

\section{HASIL DAN PEMBAHASAN \\ Analisis Regesi Linear Sederhana \\ Uji $\mathbf{H}_{1}$}

Hasil uji dalam penelitian analisis regresi linear sederhana $\mathrm{H}_{1}$ dapat dilihat dari pada Tabel dibawah ini

$\mathrm{H}_{1}$ : Pengaruh BI Rate terhadap Indeks Harga Saham JII: 
Julianto H, AL Kausar S : Pengaruh Etika Kerja Islami Terhadap Kinerja Dosen (Studi Kasus Pada Universitas Muslim Nusantara AL- Wasliyah Medan)

Analisis Regresi Linear Sederhana $\mathrm{H}_{1}$

Coefficients $^{\mathrm{a}}$

\begin{tabular}{|c|c|c|c|c|c|}
\hline \multirow[t]{2}{*}{ Model } & \multicolumn{2}{|c|}{ Unstandardized Coefficients } & $\begin{array}{l}\text { Standardized } \\
\text { Coefficients }\end{array}$ & \multirow[t]{2}{*}{$t$} & \multirow[t]{2}{*}{ Sig. } \\
\hline & B & Std. Error & Beta & & \\
\hline $1 \begin{array}{ll}\text { (Constant) } \\
\text { BI Rate }\end{array}$ & $\begin{array}{l}910,539 \\
-3402,691\end{array}$ & $\begin{array}{l}176,441 \\
2393,778\end{array}$ &,- 255 & $\begin{array}{l}5,161 \\
-1,421\end{array}$ & \begin{tabular}{|l}
, 000 \\
, 166
\end{tabular} \\
\hline
\end{tabular}

a. Dependent Variable: Indeks JII

Berdasarkan Tabel 4.1 maka persamaan analisis regesi linear sederhana dalam peneltian ini adalah:

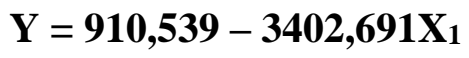

Berdasarkan persamaan tersebut dapat digambarkan sebagai berikut:

a. Konstanta sebesar 910,539 artinya jika BI Rate $\left(\mathrm{X}_{2}\right)$ dianggap bernilai 0, maka indeks JII (Y) sebesar 910,539.

b. Koefisien regresi variabel $\mathrm{BI}$ rate $\left(\mathrm{X}_{2}\right)$ sebesar $-3402,691$ dan bernilai negatif artinya terjadi hubungan negatif antara variabel BI rate $\left(\mathrm{X}_{2}\right)$ dengan indeks JII, apabila nilai indeks JII mengalami kenaikan satu satuan maka BI Rate mengalami penurunan sebesar 3402,691 .

\section{Uji Hipotesis}

\section{Uji Parsial (Uji-t)}

Pengujian ini dilakukan untuk menguji apakah variabel BI rate mempunyai pengaruh terhadap variabel indeks JII. Uji ini dilakukan dengan membandingkan thitung dengan $t_{\text {tabel }}$ dengan ketentuan sebagai berikut:

a. Jika thitung $<\mathrm{t}_{\text {tabel }}$ atau sig $>0,05$ maka $\mathrm{H}_{1}$ ditolak

b. Jika thitung $>t_{\text {tabel }}$ atau sig $<0,05$ maka $\mathrm{H}_{1}$ diterima

\section{Hasil Uji t (Uji Parsial)}

Coefficients $^{\mathrm{a}}$

\begin{tabular}{|c|c|c|c|c|c|}
\hline \multirow[t]{2}{*}{ Model } & \multicolumn{2}{|c|}{$\begin{array}{l}\text { Unstandardized } \\
\text { Coefficients }\end{array}$} & \begin{tabular}{|l|} 
Standardized \\
Coefficients
\end{tabular} & \multirow[t]{2}{*}{$\mathrm{t}$} & \multirow[t]{2}{*}{ Sig. } \\
\hline & $\mathrm{B}$ & Std. Error & Beta & & \\
\hline (Constant $)$ & $-251,122$ & 75,429 & & $-3,329$ &, 002 \\
\hline BI Rate & 2640,944 & 705,057 & , 198 & 3,746 &, 001 \\
\hline
\end{tabular}

a. Dependent Variable: Indeks JII

Sumber : Output SPSS 20 (data diolah, 2019)

Berdasarkan tabel 4.2 diatas dapat disimpulkan bahwa Variabel BI rate mempunyai nilai


dikatakan bahwa thitung $>t_{\text {tabel }}$ dan sig $<0,05$ maka $\mathrm{H}_{2}$ diterima, yang berarti BI rate berpengaruh dan signifikan terhadap indeks JII.

\section{Koefisien Determinasi $\left(\mathbf{R}^{2}\right)$}

Nilai $\mathrm{R}^{2}$ menunjukkan tingkat kemampuan semua variabel bebas untuk mempengaruhi variabel terikat, sedangkan sisanya ditentukan oleh variabel lain dari luar variabel bebas. Nilai koefisien determinasi adalah diantara nol sampai dengan satu. Semakin tinggi nilai koefisien determinasi, maka akan semakin baik pula kemampuan variabel independen dalam menjelaskan variabel dependen. Berikut merupakan hasil koefisien determinasi pada penelitian ini sebagai berikut: 
Julianto H, AL Kausar S : Pengaruh Etika Kerja Islami Terhadap Kinerja Dosen (Studi Kasus Pada Universitas Muslim Nusantara AL- Wasliyah Medan)

\begin{tabular}{|c|c|c|c|c|}
\hline \multicolumn{5}{|c|}{$\begin{array}{c}\text { Hasil Uji Koefisien Determinasi }\left(\mathbf{R}^{2}\right) \\
\text { Model Summary }\end{array}$} \\
\hline Model & $\mathrm{R}$ & R Square & \begin{tabular}{|ll} 
Adjusted & $\mathrm{R}$ \\
Square & \\
\end{tabular} & $\begin{array}{l}\text { Std. Error of } \\
\text { the Estimate }\end{array}$ \\
\hline 1 &, $968^{\mathrm{a}}$ & ,937 & 932 & 12,04193 \\
\hline
\end{tabular}

a. Predictors: (Constant), BI Rate

b. Dependent Variable: Indeks JII

Berdasarkan tabel 4.3 dapat diketahui bahwa niali Adjusted $R^{2}$ sebesar 0,932. Hal ini berarti variabel dependen yang dapat dijelaskan oleh variabel-variabel independen sebesar 93,2\%. Dan selebihnya yaitu $6,8 \%$ dijelaskan oleh variabel lain yang tidak masuk dalam variabel regresi dala peneltian ini.

\section{Pembahasan}

Berdasarkan hasil pengujian variabel bebas (BI Rate) terhadap variabel terikat (Indeks JII) yang telah diuraikan seecara statistik dengan penggunakan program SPSS ver.20, maka hipotesis dapat dijelaskan sebagai berikut:

\section{Pengaruh BI Rate Terhadap Indeks Harga Saham Jakarta Islamic Index (JII)}

Pengujian hipotesis uji t BI rate, hasilnya menunjukkan bahwa variabel tersebut juga memiliki pengaruh positif dan signifikan terhadap Indeks JII dengan nilai thitung $(3,746)>$ $t_{\text {tabel }}(2,048)$ dengan tingkat signifikan $0,001<0,05$ maka $\mathrm{H}_{2}$ diterima. Hal ini menandakan bahwa semakin besar nilai BI rate maka akan semakin berdampak pada meningkatnya angka indeks JII. Berbeda dengan teori oleh Azis (2015) yang menyebutkan bahwa tingkat suku bunga dapat mempengaruhi persaingan di pasar modal antara saham dan obligasi, apabila suku bunga naik, maka investor akan mandapatkan hasil yang besar dari obligasi sehingga mereka akan segera menjual saham mereka untuk ditukarkan dengan obligasi, penukaran yang demikian akan menurunkan harga saham. Hal sebaliknya juga terjadi apabila tingkat suku bunga mempengaruhi harga saham secara negatif, artinya bila tingkat suku bunga turun maka harga saham akan naik. Namun teori tersebut sejalan dengan hasil pengujian regresi linear sederhana BI rate. Hasil olahan data menunjukkan bahwa BI rate dan Indeks JII memiliki hubungan yang negatif. Hasil dari penelitian sebelumnya juga menunjukkan hasil yang berbeda, penelitian yang dilakukan oleh Hafidz (2015) menunjukkan BI rate tidak berpengaruh signifikan terhadap indeks JII. Sedangkan penelitian yang dilakukan oleh Ayu dan Leo (2015) menunjukkan BI rate berpengaruh signifikan negatif terhadap indeks JII

\section{KESIMPULAN}

Dari hasil penelitian dan pembahasan yang dilakukan, peneliti memperoleh kesimpulan bahwa secara parsial, variabel BI Rate berpengaruh positif dan signifikan terhadap indeks harga saham Jakarta Islamic Index (JII) yang berarti bahwa semakin besar nilai BI Rate yang dikeluarkan oleh Bank Indonesia maka akan berdampak pada meningkatnya indeks harga saham Jakarta Islamic Index (JII).

\section{DAFTAR PUSTAKA}

Azis, Mudalifah, dkk. 2015. Manajemen Investasi Fundamental, Teknikal, Perilaku Investor dan Return Saham. Yogyakarta: Deepublish

DSN MUI, Hak Memesan Efek Terlebih Dahulu Syariah, Fatwa DSN MUI. No. 65/DSNMUI/III/2008 Tentang Hak Memesan Efek Terlebih Dahulu Syariah

DSN MUI, Obligasi Syariah, Fatwa DSN MUI. No. 32/DSN MUI/IX/2002 Tentang Obligasi Syariah 
Julianto H, AL Kausar S : Pengaruh Etika Kerja Islami Terhadap Kinerja Dosen (Studi Kasus Pada Universitas Muslim Nusantara AL- Wasliyah Medan)

DSN MUI, Pasar Modal dan Pedoman Umum Penerapan Prinsip Syariah di Bidang Pasar Modal, Fatwa DSN MUI. No 40/DSN-MUI/X/2003 Tentang Pasar Modal dan Pedoman Umum Penerapan Prinsip Syariah di Bidang Pasar Modal

DSN MUI, Warran Syariah, Fatwa DSN MUI. No. 66/DSN-MUI/III/2008 Tentang Warran Syariah

Fitriyani, Ika dan Loe Herlambang. 2016. Analisis Pengaruh Variabel Makroekonomi dan Harga Komoditas Terhadap Jakarta Islamic Index. Jurnal Ekonomi Syariah Teori dan Terapan Vol. 3 No. 9

Ghozali, Imam. 2013. Aplikasi Analisis Multivariate dengan Program IBM SPSS 21. Semarang: Badan Penerbit Universitas Diponegoro

Hidayat, Taufik. 2011. Buku Pintar Investasi Syariah. Jakarta: Media Kita

Martono, Nanang. 2012. Metode Penelitian Kuantitatif Analisis Isi dan Analisis Data Sekunder. Jakarta: Raja Wali Pers.

Mufrenl, Alfin NF dan Dhea Amanah. 2015. Pengaruh Kapitalisasi Pasar dan Likuiditas Saham Terhadap Harga Saham Pada PT. Astra Internasional Tbk. Jurnal Ekonomi Manajemen Vol. 1 No. 1

Pratama, Yoghi Citra. 2012. Pengaruh Indeks Regional Terhadap Jakarta Islamic Index (JII). Jurnal Etikonomi Vol. 11 No.2

Republik Indonesia. 1995. Undang-Undang No. 8 Tahun 1995 tentang Pasar Modal. Sekretariat Negara. Jakarta.

Shidiq, Hafidz Ash dan Azis Budi Setiawan. 2015. Analisis Pengaruh Suku Bunga SBI, Uang Beredar, Inflasi, dan Nilai Tukar Terhadap Indeks Harga Saham Jakarta Islamic Index (JII) Periode 2009-2014: Jurnal Ekonomi dan Perbankan Syariah Vol. 3 No. 2

Soemitra, Andri. 2015. Bank dan Lembaga Keuangan Syariah. Medan: Kencana.

Sugiyono. 2012. Metode Penelitian Bisnis. Bandung: Alfabeta.

Tan, Anton. 2014. The Real Secret of Successful Investor and Developer. Jakarta: Elex Media Komputindo 